\title{
Acute toxicity test of detergent powder in silver carp (Hypophthal- micthys molitrix), common carp (Cyprinus carpio), goldfish (Carassius auratus) and roach (Rutilus rutilus caspicus)
}

\author{
A Hedayati ${ }^{1}$ and AP Salati ${ }^{2}$ \\ ${ }^{1}$ Department of Fisheries, Faculty of Fisheries and Environment, Gorgan University of Agricultural Sciences \\ and Natural Resources, Gorgan, Iran \\ ${ }^{2}$ Department of Fisheries, Faculty of Marine Natural Resources, Khoramshar University of Marine Science and \\ Technology, Khorramshahr, Iran
}

Recived: August 2015

\begin{abstract}
Different pollutants have undesirable effects on aquatic ecosystems, detergent powder is one of the elements in the sewages so study on the effects of this factor on aquatic animals is crucial. The aim of the present study was to investigate acute effects of detergents as potentially dangerous additive to assess mortality effects of this product on some cultured fish. Silver Carp (Hypophthalmicthys molitrix), Common Carp (Cyprinus carpio), Goldfish (Carassius auratus) and Roach (Rutilus rutilus caspicus) were exposed to the $0,2,10,20$ and 40 mg L-1 of detergent powder. All experiments were done according the standard methods for $96 \mathrm{~h}$ exposure. LC50 was determined by probit analysis. The 96h toxicity tests showed $100 \%$ mortality at $40 \mathrm{mg}$ L-1, and no mortality was observed in $5 \mathrm{mg} \mathrm{L}-1$ for all species. LC50 of detergent powder in Goldfish (24.6 $\pm 0.32 \mathrm{mg} \mathrm{L}-1)$ was higher than other species, while silver carp (16.7 mg L-1) had the lowest one.
\end{abstract}

Keywords: Fish, LC50, Toxicity test, Detergent powder.

\section{Introduction}

Acute toxicity tests help us to identify the mode of

Correspondence A Hedayati, Department of Fisheries , Faculty of Fisheries and Environment, Gorgan University of Agricultural Sciences and Natural Resources, Gorgan, Iran (e-mail: Hedayati@gau.ac.ir)
Accepted: December 2015

action of toxic substances and may provide information on doses associated with target-organ toxicity and lethality. The results from acute toxicity tests can provide information for comparison of toxicity and dose-response among members of chemical classes (Hedayati, Safahieh, Savari \& Ghofleh Marammazi 2010a).

Detergents are important pollutants of the aquatic environments. They usually contain water softeners, processing acids, cleaning agents, anti redeposition agents, optical brighteners, perfume and colorings (Okoli-Anunobi, Ufodike \& Chude 2002). Although many studies have been conducted on the toxicity of surfactants on aquatic organisms, there is not enough information about the impact of detergents on fish physiologic status. Fish exposed to detergents cannot identify the quality of diet (Cairns \& Lloos 1967) and will die when exposed to high doses of detergents (Chattopodhyay \& Koner 1985). LC50 is the ambient aqueous chemical activity causes $50 \%$ mortality in an exposed population. The amount of LC50 is based on two important assumptions. The first assumption is that the exposure time associated with the specified LC50 is sufficient to allow almost complete chemical equilibration between the fish and the water. The second assumption is that the specified one is the minimum LC50 that kills the fish during the associated exposure interval. Fortunately, most reliable LC50 satisfies these two assumptions (Boudou \& Ribeyre 1997).

This study was done to evaluate effects of detergents on some valuable cultured fish of Iran, Silver Carp (Hypophthalmicthys molitrix), Common Carp 


\section{A Hedayati et al., Toxicity of detergent powder in freshwater fish}

(Cyprinus carpio), Goldfish (Carassius auratus) and Roach (Rutilus rutilus caspicus).

\section{Materials and Methods}

Acute toxicity tests were conducted on common carp (mean weight $18 \pm 2.85 \mathrm{~g}$, SL $12 \pm 1.76 \mathrm{~cm}$ ), silver carp (mean weight $45 \pm 3.64 \mathrm{~g}$, \& SL $18 \pm 2.04$ $\mathrm{cm}$ ), Goldfish (mean weight $15 \pm 1.6 \mathrm{~g} \&$ SL $7 \pm 0.3$ $\mathrm{cm}$ ) and Roach (mean weight $3.5 \pm 0.21 \mathrm{~g}$, SL $7 \pm 1.10$ $\mathrm{cm})$. Only healthy fish, as indicated by their activity and external appearance, were maintained alive on board in a fiberglass tank. Samples transferred to a $400 \mathrm{~L}$ aerated tank with $200 \mathrm{~L}$ of test medium.

All samples were acclimated for one week in 15 aerated fiberglass tanks at $25^{\circ} \mathrm{C}$ under a constant 12 h Light and 12 h Dark photoperiod. Acclimatized fish were fed daily with a commercial plate (Roshd daneh, Gorgan, Iran). Dead fish were immediately removed with special plastic forceps to avoid possible deterioration of the water quality (Gooley, Gavine, Dalton, De Silva, Bretherton \& Samblebe 2000)

Prior to the study, a range-finding test was done to determine the concentrations to be used (OECD 1992). Concentration selection was based on the mortality rate obtained in the range-finding test. For control group nothing was added to water. Daily observations for fish mortality were made during the test period. Fish were considered dead when they failed to respond to gentle prodding (OECD 1992). Acute toxicity tests were carried out in order to calculate the 96h-LC50 for detergent powder, based on Hotos \& Vlahos (1998). Detergent powder tested concentrations were 2, 5, 10, 20 and $40 \mathrm{mg} \mathrm{L}-1$. Each treatment was done in triplicate. Test medium was not renewed during the assay and no food was provided to the animals. Values of the mortalities were measured at time 0, 24, 48, 72 and $96 \mathrm{~h}$ (Hedayati, Safahieh, Savari \& Ghofleh Marammazi 2010b).

LC50 values were calculated from the data obtained in acute toxicity bioassays, by Finney's (1971) method of "probit analysis" and with SPSS computer statistical software. In Finney's method, the LC50 value is derived by fitting a regression
Table 1 Cumulative mortality of common carp during acute exposure to detergent powder ( $\mathrm{n}=21$, each concentration).

\begin{tabular}{lllll}
\hline \multirow{2}{*}{$\begin{array}{l}\text { Concentration } \\
(\mathrm{mg} \mathrm{L}-1)\end{array}$} & \multicolumn{3}{l}{ No. of mortality } \\
\cline { 2 - 5 } & $24 \mathrm{~h}$ & $48 \mathrm{~h}$ & $72 \mathrm{~h}$ & $96 \mathrm{~h}$ \\
\hline Control & 0 & 0 & 0 & 0 \\
2 & 0 & 0 & 0 & 0 \\
10 & 0 & 0 & 0 & 0 \\
20 & 0 & 0 & 2 & 6 \\
40 & 17 & 20 & 21 & 21 \\
\hline
\end{tabular}

Table 2 Cumulative mortality of silver carp during acute exposure to detergent powder ( $\mathrm{n}=7$, each concentration).

\begin{tabular}{lllll}
\hline $\begin{array}{l}\text { Concentration } \\
(\mathrm{mg} \mathrm{L}-1)\end{array}$ & \multicolumn{4}{l}{ No. of mortality } \\
\cline { 2 - 5 } & $24 \mathrm{~h}$ & $48 \mathrm{~h}$ & $72 \mathrm{~h}$ & $96 \mathrm{~h}$ \\
\hline Control & 0 & 0 & 0 & 0 \\
2 & 0 & 0 & 0 & 0 \\
10 & 0 & 0 & 0 & 0 \\
20 & 1 & 2 & 3 & 6 \\
40 & 19 & 21 & 21 & 21 \\
\hline
\end{tabular}

Table 3 Cumulative mortality of Roach during acute exposure to detergent powder ( $\mathrm{n}=7$, each concentration).

\begin{tabular}{lllll}
\hline $\begin{array}{l}\text { Concentration } \\
\text { (mg L-1) }\end{array}$ & \multicolumn{3}{l}{ No. of mortality } & \\
\cline { 2 - 5 } & $24 \mathrm{~h}$ & $48 \mathrm{~h}$ & $72 \mathrm{~h}$ & $96 \mathrm{~h}$ \\
\hline Control & 0 & 0 & 0 & 0 \\
2 & 0 & 0 & 0 & 0 \\
10 & 0 & 1 & 3 & 4 \\
20 & 18 & 18 & 21 & 21 \\
40 & 21 & 21 & 21 & 21 \\
\hline
\end{tabular}

Table 4 Cumulative mortality of goldfish during acute exposure to detergent powder ( $\mathrm{n}=7$, each concentration).

\begin{tabular}{lllll}
\hline $\begin{array}{l}\text { Concentration } \\
\text { (mg L-1) }\end{array}$ & \multicolumn{4}{l}{ No. of mortality } \\
\cline { 2 - 5 } & $24 \mathrm{~h}$ & $48 \mathrm{~h}$ & $72 \mathrm{~h}$ & $96 \mathrm{~h}$ \\
\hline Control & 0 & 0 & 0 & 0 \\
2 & 0 & 0 & 0 & 0 \\
10 & 0 & 0 & 0 & 0 \\
20 & 0 & 0 & 1 & 3 \\
40 & 17 & 21 & 21 & 21 \\
\hline
\end{tabular}

equation arithmetically and also by graphical interpolation by taking logarithms of the test chemical concentration on the $\mathrm{X}$ axis and the probit value of percentage mortality on the Y axis (Finney 1971).

\section{Results}

The mortality rate of studying fishes for detergent powder doses $0,2,10,20$ and $40 \mathrm{mg} \mathrm{L}-1$ were ex- 
Iranian Journal of Aquatic Animal Health

Table 5 Lethal Concentrations (LC1-99) of detergent powder (mean \pm Standard Error) depending on time (24-96h) for common carp.

\begin{tabular}{|c|c|c|c|c|}
\hline \multirow[t]{2}{*}{ Point } & \multicolumn{4}{|c|}{ Concentration (mg L-1) (95\% of confidence limits) } \\
\hline & $24 \mathrm{~h}$ & $48 \mathrm{~h}$ & $72 \mathrm{~h}$ & $96 \mathrm{~h}$ \\
\hline $\mathrm{LC} 1$ & $20.8 \pm 0.16$ & $20.8 \pm 0.16$ & $20.8 \pm 0.16$ & $13.5 \pm 0.50$ \\
\hline LC10 & $24.6 \pm 0.16$ & $24.6 \pm 0.16$ & $24.6 \pm 0.16$ & $17.3 \pm 0.50$ \\
\hline LC30 & $27.5 \pm 0.16$ & $27.5 \pm 0.16$ & $27.5 \pm 0.16$ & $20.0 \pm 0.50$ \\
\hline LC50 & $29.4 \pm 0.16$ & $29.4 \pm 0.16$ & $29.4 \pm 0.16$ & $22.0 \pm 0.50$ \\
\hline LC70 & $31.4 \pm 0.16$ & $31.4 \pm 0.16$ & $31.4 \pm 0.16$ & $23.9 \pm 0.50$ \\
\hline LC90 & $34.2 \pm 0.16$ & $34.2 \pm 0.16$ & $34.2 \pm 0.16$ & $26.6 \pm 0.50$ \\
\hline LC99 & $38.1 \pm 0.16$ & $38.1 \pm 0.16$ & $38.1 \pm 0.16$ & $30.4 \pm 0.50$ \\
\hline
\end{tabular}

Table 6 Lethal Concentrations (LC1-99) of detergent powder (Mean \pm SE) depending on time (24-96 h) for silver carp.

\begin{tabular}{|c|c|c|c|c|}
\hline \multirow[t]{2}{*}{ Point } & \multicolumn{4}{|c|}{ Concentration (mg L-1) (95 \% of confidence limits) } \\
\hline & $24 \mathrm{~h}$ & $48 \mathrm{~h}$ & $72 \mathrm{~h}$ & $96 \mathrm{~h}$ \\
\hline LC1 & $20.8 \pm 0.16$ & $14.6 \pm 0.32$ & $14.6 \pm 0.32$ & $13.5 \pm 0.50$ \\
\hline LC10 & $24.6 \pm 0.16$ & $19.1 \pm 0.32$ & $19.1 \pm 0.32$ & $17.3 \pm 0.50$ \\
\hline LC30 & $27.5 \pm 0.16$ & $22.3 \pm 0.32$ & $22.3 \pm 0.32$ & $20.0 \pm 0.50$ \\
\hline LC50 & $29.4 \pm 0.16$ & $24.6 \pm 0.32$ & $24.6 \pm 0.32$ & $22.0 \pm 0.50$ \\
\hline LC70 & $31.4 \pm 0.16$ & $26.8 \pm 0.32$ & $26.8 \pm 0.32$ & $23.9 \pm 0.50$ \\
\hline LC90 & $34.2 \pm 0.16$ & $30.1 \pm 0.32$ & $30.1 \pm 0.32$ & $26.6 \pm 0.50$ \\
\hline LC99 & $38.1 \pm 0.16$ & $34.6 \pm 0.32$ & $34.6 \pm 0.32$ & $30.4 \pm 0.50$ \\
\hline
\end{tabular}

Table 7 Lethal Concentrations (LC1-99) of detergent powder (Mean \pm SE) depending on time (24-96 h) for Roach.

\begin{tabular}{|c|c|c|c|c|}
\hline \multirow[t]{2}{*}{ Point } & \multicolumn{4}{|c|}{ Concentration (mg L-1 ) (95\% of confidence limits) } \\
\hline & $24 \mathrm{~h}$ & $48 \mathrm{~h}$ & $72 \mathrm{~h}$ & $96 \mathrm{~h}$ \\
\hline LC1 & $11.0 \pm 0.33$ & $11.0 \pm 0.33$ & $7.06 \pm 0.50$ & $7.06 \pm 0.50$ \\
\hline $\mathrm{LC} 10$ & $12.9 \pm 0.33$ & $12.9 \pm 0.33$ & $9.46 \pm 0.50$ & $9.46 \pm 0.50$ \\
\hline $\mathrm{LC} 30$ & $14.3 \pm 0.33$ & $14.3 \pm 0.33$ & $11.2 \pm 0.50$ & $11.2 \pm 0.50$ \\
\hline LC50 & $15.3 \pm 0.33$ & $15.3 \pm 0.33$ & $12.4 \pm 0.50$ & $12.4 \pm 0.50$ \\
\hline $\mathrm{LC} 70$ & $16.3 \pm 0.33$ & $16.3 \pm 0.33$ & $13.6 \pm 0.50$ & $13.6 \pm 0.50$ \\
\hline LC90 & $17.7 \pm 0.33$ & $17.7 \pm 0.33$ & $15.3 \pm 0.50$ & $15.3 \pm 0.50$ \\
\hline LC99 & $19.6 \pm 0.33$ & $19.6 \pm 0.33$ & $17.7 \pm 0.50$ & $17.7 \pm 0.50$ \\
\hline
\end{tabular}

Table 8 Lethal Concentrations (LC1-99) of detergent powder (Mean \pm SE) depending on time (24-96 h) for goldfish.

\begin{tabular}{|c|c|c|c|c|}
\hline \multirow[t]{2}{*}{ Point } & \multicolumn{4}{|c|}{ Concentration (mg L-1) (95\% of confidence limits) } \\
\hline & $24 \mathrm{~h}$ & $48 \mathrm{~h}$ & $72 \mathrm{~h}$ & $96 \mathrm{~h}$ \\
\hline LC1 & $20.8 \pm 0.16$ & $20.8 \pm 0.16$ & $20.8 \pm 0.16$ & $14.6 \pm 0.32$ \\
\hline $\mathrm{LC} 10$ & $24.6 \pm 0.16$ & $24.6 \pm 0.16$ & $24.6 \pm 0.16$ & $19.1 \pm 0.32$ \\
\hline $\mathrm{LC} 30$ & $27.5 \pm 0.16$ & $27.5 \pm 0.16$ & $27.5 \pm 0.16$ & $22.3 \pm 0.32$ \\
\hline LC50 & $29.4 \pm 0.16$ & $29.4 \pm 0.16$ & $29.4 \pm 0.16$ & $24.6 \pm 0.32$ \\
\hline $\mathrm{LC} 70$ & $31.4 \pm 0.16$ & $31.4 \pm 0.16$ & $31.4 \pm 0.16$ & $26.8 \pm 0.32$ \\
\hline LC90 & $34.2 \pm 0.16$ & $34.2 \pm 0.16$ & $34.2 \pm 0.16$ & $30.1 \pm 0.32$ \\
\hline LC99 & $38.1 \pm 0.16$ & $38.1 \pm 0.16$ & $38.1 \pm 0.16$ & $34.6 \pm 0.32$ \\
\hline
\end{tabular}

amined during the exposure times in 24, 48, 72 and $96 \mathrm{~h}$ (Tables 1-3). During of acute test, numbers of dead fish showed a positive relation to concentration of detergents, and a significant difference have been found between species after $96 \mathrm{~h}$. There was $100 \%$ mortality at $40 \mathrm{mg} \mathrm{L}-1$ concentration after $96 \mathrm{~h}$ for 


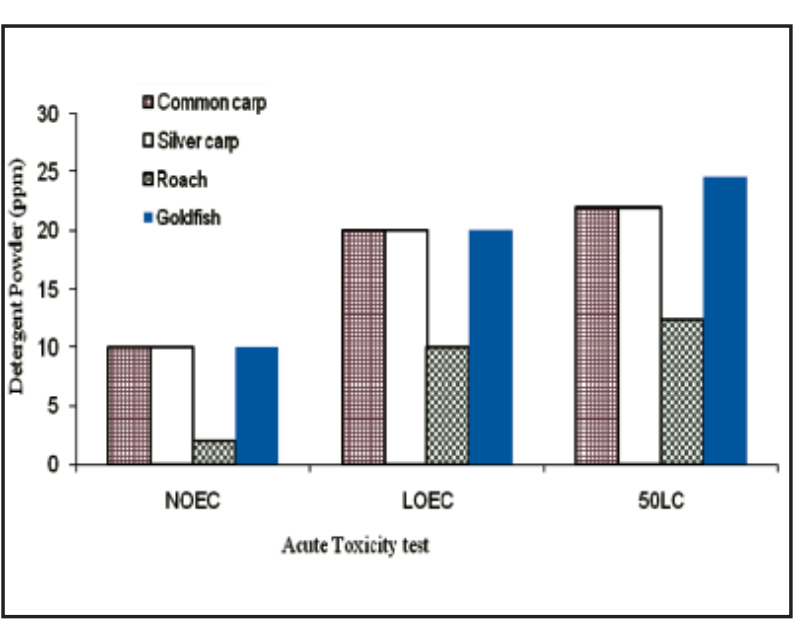

Figure 1 Comparisons of some toxicity statistical indices of detergent powder in common carp, silver carp, roach and goldfish.

the common carp, silver carp and goldfish; however $100 \%$ mortality recorded for the roach at 20 and 40 mg L-1 concentrations at the same time. Also, there was no mortality at 2 and $10 \mathrm{mg} \mathrm{L}-1$ concentrations within the exposure times for the common carp, silver carp and goldfish, accompanied with no mortality at $2 \mathrm{mg} \mathrm{L}-1$ concentration within the $96 \mathrm{~h}$ after dosing for the roach.

Lethal concentrations of $1,10,30,50,70,90$ and $99 \%$ test are in Tables 4-8. Because mortality (or survival) data were collected for each exposure concentration in a toxicity test at various exposure durations $(24,48,72$, or $96 \mathrm{~h})$, data can be plotted in other ways; the straight line of best fit is then drawn through the points.

Toxicity Testing Statistical Endpoints can be found in Figure 1. LOEC (Lowest Observed Effect Concentration) and NOEC (No Observed Effect Concentration) were the same for all studied fishes except roach. However, LC50 had a significant difference among studied species $(\mathrm{P}<0.05)$. The Maximum Acceptable Toxicant Concentration (MATC) for the common carp, silver carp, goldfish and roach were 2.2, 2.2, 2.4 and $1.2 \mathrm{mg} \mathrm{L}-1$ of Detergent, respectively.

\section{Discussion}

An acute toxicity test is first conducted to estimate the lethal concentration (LC50) of the chemical in water to which organisms are exposed (Di Giulio $\&$ Hinton 2008). The correlation between mortality and the quantity of test chemical are always assumed a concentration-response form. LC50 of detergents has been reported for Onchorhynchus mykiss 25.11 mg L-1 (Tomoregie \& Okwuosa 2005), Rutilus frisii caspicus $12.2 \mathrm{mg} \mathrm{L}-1$ (Tehrani 2000), Nile tilapia $7.64 \mathrm{mg}$ L-1 (Omotoso \& Fagbentro 2005). Variability in acute toxicity even in a single species and single toxicant are depended on the size, age, and condition of the test species along with experimental factors, however, differences in acute toxicity may be due to changes in water quality and test species (Rathore \& Khangarot 2002).

In the present study, LC50 values indicated that detergent powder (Condor Company, Semnan, Iran) was toxic to cultured fishes, especially silver carp. LC50 obtained in the present study in comparison with corresponding values that have been published in the literature for other species of fish, showed different LC50 of detergent powder in different species and even different time, but lower values of LC50 for studied fish were obtained in this study has more importance, as confirmed sensitively of the used species to low detergent powder doses. Although the LC50 under a defined set of environmental conditions can provide useful information, the numeric value cannot be used in the field, so in continue some ecophysiological indices of cultured fishes should be measured for better understanding of detergent powder toxicity.

\section{Acknowledgement}

This study was done by financial support of the Gorgan University of Agriculture \& Natural Resource.

\section{References}

Boudou A. \& Ribeyre F. (1997) Aquatic ecotoxicology: from the ecosystem to the cellular and molecular levels. Environmental Health Perspective 105, 21-35.

Cairns J.R. \& Lloos J.J. (1967) Changed feeding rate of Brachyyodanio ratio resulting from exposure to subleth- 
al concentration of zinc, potassium dichromate and alkyl benzene sufonate detergent. Proceeding of the Pennsylvanian Academy of Science 40, 47-52.

Chattopodhyay D.N. \& Konar S.K. (1985) Chronic effects of an anionic detergent on aquatic ecosystems. Environmental Ecology 3, 82-85.

Di Giulio R.T. \& Hinton D.E. (2008) The Toxicology of Fishes. Taylor \& Francis.

Finney D.J. (1971) Probit Analysis. Univ. Press, Cambridge.

Gooley G.J., Gavine F.M., Dalton W., De Silva S.S., Bretherton M. \& Samblebe M. (2000) Feasibility of aquaculture in dairy manufacturing wastewater to enhance environmental performance and offset costs. Final Report DRDC Project No. MAF001. Marine and Freshwater Resources Institute, Snobs Creek.

Hedayati A., Safahieh A., Savari A. \& Ghofleh Marammazi J. (2010a) Detection of mercury chloride acute toxicity in Yellowfin sea bream. World Journal of Fish and Marine Science 2, 86-92.

Hedayati A., Safahieh A., Savari A. \& Ghofleh Marammazi J. (2010b) Assessment of aminotransferase enzymes in Yellowfin sea bream under experimental condition as biomarkers of mercury pollution. World Journal of Fish and Marine Science 2, 186-192.

Hotos G.N. \& Vlahos N. (1998) Salinity tolerance of Mugil cephalus and Chelon labrosus, Pisces: Mugilidae fry in experimental conditions. Aquaculture 167, 329-338 National Research Council. (1985) Oil in the Sea, Inputs, Fates, and Effects. National Academy Press, Washington, DC.

Okoli-Anunobi C., Ufodike E.B.C. \& Chude L.A. (2002) Lethal effects of the detergent, Elephant Blue ${ }^{\varpi}$ on the Nile tilapia, Oreochromis niloticus. Journal of Aquatic Sciences 17, 95-97.

Omotoso F.O. \& Fagbenro O.A. (2005) A comparative study on the toxicity of three commercial detergents on the survival of the Nile Tilapia, Oreochromis niloticus. Journal of Agriculture Research and Development 4 (2), 139- 147.

Organisation for Economic Co-operation and Development (OECD) (1992) Fish, acute toxicity test. OECD Guideline for testing chemicals, Paris.

Rathore R.S. \& Khangarot B.S. (2002) Effect of temperature on the sensitivity of sludge worm Tubifex tubifex (Muller) to selected heavy metals. Ecotoxicology and Environmental Safety 53, 27-36.

Tehrani A. (2000) Determination of LC50 (Laminar anionic detergent) and diazinon on white fish and rutile of Caspian sea. M.Sc. thesis, University of Tarbiat Modarres, Tehran, Iran.

Tomoregie E. \& Okwuosa V.N. (2005) Acute toxicity of Alkyl benzene sulfonate (ABS) detergent to the Toothead carp, Aphyosemion gairdneri (L.). Journal of Aquaculture Research 26, 755-758. 


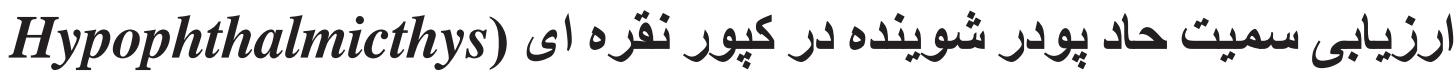

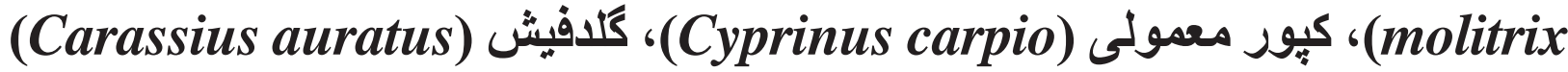 و كلمه (Rutilus rutilus caspicus)
}

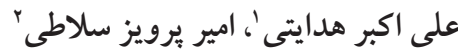

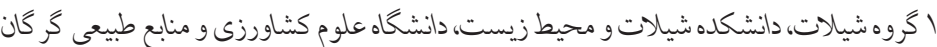

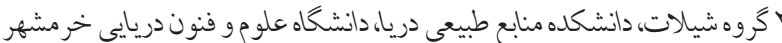

آلايندههاى زيادى اكوسيسـتم آبى را تحت تأثير قرار مىدهند. يودر شـــينده موجود در سيسـتم فاضلاب از جمله اين آلايندهها مىباشد، بنابر اين

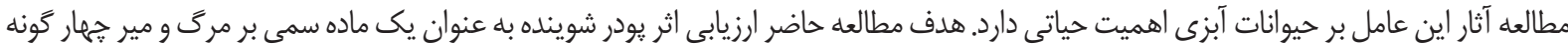
از ماهيان تجارى رايج بود. بدين منظور ماهيان كيور نقرهاى (Hypophthalmicthys molitrix)، كيور معمولى (Cyprinus carpio)، كلدفيش

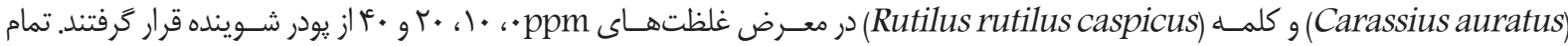

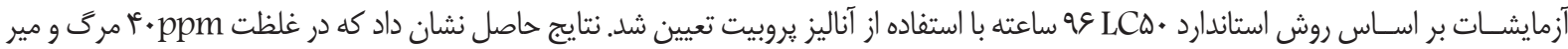

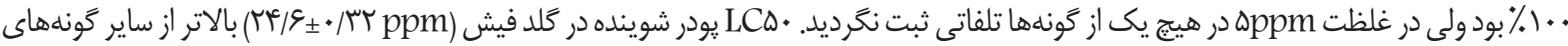

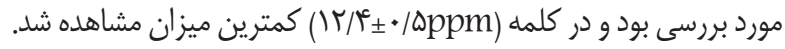
واثههاى كليدى: ماهى، •LCD، سميت، يودر شوينده. Hedayati@gau.ac.ir :ويسنده مسئول* 